\title{
Effects of Wnt5a protein on proliferation and apoptosis in JAR choriocarcinoma cells
}

\author{
SHA PENG, JUNLIN ZHANG, JIAHUAN CHEN and HUAYAN WANG \\ Shaanxi Key Laboratory of Molecular Biology for Agriculture, Shaanxi Stem Cell Engineering and Technology \\ Research Center, College of Veterinary Medicine, Northwest A\&F University, Shaanxi 712100, P.R. China
}

Received July 30, 2010; Accepted October 14, 2010

DOI: $10.3892 / \mathrm{mmr} .2010 .383$

\begin{abstract}
Placental choriocarcinoma is a highly malignant tumor of the female reproductive organs. Even with chemotherapy, placental choriocarcinoma has a $20 \%$ mortality rate due to its indistinct pathogenesis and the absence of efficient therapeutic methods for this cancer. Wnt proteins and Wnt signaling are involved in a variety of developmental and cellular processes, and aberrant activation of Wnt signaling is linked to carcinogenesis in many types of tissue. In the present study, using immunostaining and reverse transcription PCR, we found that Wnt5a was prominently expressed in human primary cytotrophoblast cells, but absent in the human choriocarcinoma cell line JAR. This implies that there is a previously unknown correlation between Wnt5a and placental choriocarcinoma. Furthermore, we found that the addition of exogenous recombinant Wnt5a protein to the JAR cells repressed their proliferation and induced apoptosis, indicating that Wnt5a has a tumor suppressive effect in placental choriocarcinoma. In conclusion, the results of the present study suggest that there is a correlation between Wnt5a and human placental choriocarcinoma; therefore, Wnt5a has a potential use in the treatment of this malignancy.
\end{abstract}

\section{Introduction}

The first requirements for embryonic development are implantation in the uterus and the formation of hemachorial placenta, in which trophoblast cells enable embryo invasion deep into the stroma through the uterine epithelium (1). This process is strictly regulated in a temporal and spatial pattern. Too shallow or excess invasion may result in pregnancy abnormalities, such as preeclampsia or placental choriocarcinoma (2).

Correspondence to: Dr Sha Peng and Dr Huayan Wang, Shaanxi Key Laboratory of Molecular Biology for Agriculture, Shaanxi Stem Cell Engineering and Technology Research Center, College of Veterinary Medicine, Northwest A\&F University, Yangling, Shaanxi 712100, P.R. China

E-mail: pengsha123@yahoo.com.cn; hhwang101@163.com

Key words: choriocarcinoma, Wnt5a, proliferation, apoptosis
Placental choriocarcinoma is a malignant cancer of the reproductive system. Even with chemotherapy, it has a mortality rate of $20 \%$ due to its indistinct pathogenesis and the absence of efficient therapeutic methods.

Wnts are secreted as glycosylated lipid-modified cysteine-rich proteins (3) and play crucial roles in embryonic development, morphogenesis, cell proliferation, differentiation and migration (4-6). Wnt signaling includes the canonical (Wnt $/ \beta$-catenin, CTNNB1) and non-canonical (Wnt $/ \mathrm{Ca}^{2+}$ ) pathways $(7,8)$. A less described Wnt pathway is the Wnt-JNK pathway (9). It has been suggested that Wnt5a, which increases intracellular $\mathrm{Ca}^{2+}$ levels through the activation of protein kinase $\mathrm{C}$ and $\mathrm{Ca}^{2+} /$ calmodulin-dependent kinase II, operates through the Wnt/Ca ${ }^{2+}$ signaling pathway $(10,11)$.

In numerous previous studies, increased $\beta$-catenin signaling in tumorigenesis was found to be accompanied by elevated transcription of the genes involved in cell proliferation (12). However, the function of non-canonical Wnt/Ca ${ }^{2+}$ signaling in cancer has not been elucidated as thoroughly. Recent studies suggest that Wnt5a is related to the aggressiveness of certain malignancies, such as prostate and colorectal cancer $(13,14)$. However, its exact role during the carcinogenesis of placental choriocarcinoma remains unknown. In this study, we examined the expression of Wnt5a in primary human cytotrophoblast (CTB) cells and in the placental choriocarcinoma cell line JAR. Wnt5a was found to be expressed in CTB cells, but absent in JAR cells. Furthermore, the addition of recombinant Wnt5a protein was found to suppress proliferation and promote serum starvation-induced apoptosis in JAR cells. This suggests that Wnt5a has a tumor suppressive effect on placental choriocarcinoma, which may function through the inhibition of the canonical Wnt/ $\beta$-catenin signaling pathway.

\section{Materials and methods}

Human sample collection and primary CTB cell isolation. Samples of normal first trimester placental tissue were obtained from the Maternal and Child Health Hospital of Shaanxi Province after termination of pregnancy between 8 and 12 weeks of gestation. Official consent was provided by the patients and the project was approved by the ethics committee of Northwest A\&F University.

A modified method described by $\mathrm{Xu}$ et al (15) was used to isolate and culture CTB cells. Briefly, human chorionic 
villi tissues were digested with $0.25 \%$ trypsin for $1 \mathrm{~h}$ at $4^{\circ} \mathrm{C}$ and with $15 \mathrm{IU} / \mathrm{ml}$ DNase I (Sigma, St. Louis, MO, USA; all reagents from Sigma unless otherwise specified) for $15 \mathrm{~min}$ at room temperature. The cells were plated at 1 to $2 \times 10^{5}$ cells/ well in 24-well plates coated with collagen I, and cultured in serum-free FD medium containing 1:1 Ham F12 (Gibco, Grand Island, NY, USA) and Dulbecco's modified Eagle's medium (DMEM) supplemented with $1 \mathrm{ng} / \mathrm{ml}$ epidermal growth factor, $10 \mu \mathrm{g} / \mathrm{ml}$ insulin, $0.1 \%$ BSA, $1.75 \mathrm{mM}$ Hepes and $2 \mathrm{mM}$ glutamine. The cells were then incubated at $37^{\circ} \mathrm{C}$, $5 \% \mathrm{CO}_{2}$ in a humidified incubator in order to yield CTB cells with a high purity, determined as cells positively stained for cytokeratin and gonadotropin releasing hormone (GnRH), and negative for vimentin (Fig. 1). JAR, a human choriocarcinoma cell line, was cultured in DMEM supplemented with $10 \%$ fetal bovine serum at $37^{\circ} \mathrm{C}, 5 \% \mathrm{CO}_{2}$.

Total RNA extraction and semi-quantitative RT-PCR. Total RNA was extracted using TRIzol Reagents (Invitrogen, Carlsbad, CA, USA) according to the manufacturer's instructions. RNA was dissolved in $20 \mu 1$ nuclease-free water. RT-PCR was performed according to a coupled one-step procedure using the Access RT-PCR System (Promega, Madison, WI, USA). Briefly, $2 \mu \mathrm{g}$ of total RNA was reverse transcribed at $37^{\circ} \mathrm{C}$ for $1 \mathrm{~h}$, denatured at $94^{\circ} \mathrm{C}$ for $2 \mathrm{~min}$ and amplified for 30 cycles of denaturation at $94^{\circ} \mathrm{C}$ for $30 \mathrm{sec}$, primer annealing at $55^{\circ} \mathrm{C}$ for $30 \mathrm{sec}$ and extension at $72^{\circ} \mathrm{C}$ for $45 \mathrm{sec}$, with a final extension step of $10 \mathrm{~min}$ at $72^{\circ} \mathrm{C}$. The amplified products were analyzed by electrophoresis on a $1 \%$ agarose gel. Images of the RT-PCR ethidium bromide-stained agarose gels were acquired with a High Performance CCD camera. $\beta$-actin was used as an internal control. The sequences of specific primers were as follows: Wnt5a, F: 5' CGAAGACAGGCATCAAAGAA 3', R: 5'-GCAAAGCGGTAGCCATAGTC-3'; $\beta$-actin, F: 5'-TGG AATCCTGTGGCATCCATGAAAC-3', R: 5'-TAAAACGCA GCTCAGTAACAGTCCG-3'.

Immunofluorescence. Cells were fixed in $4 \%$ paraformaldehyde and blocked with $5 \%$ BSA before incubation at $4{ }^{\circ} \mathrm{C}$ overnight with goat anti-Wnt5a (AF645; R\&D Systems Inc.), rabbit anti$\beta$-catenin (RB-1491-P0; NeoMarkers Biotechnology, Fremont, CA, USA), rat anti-vimentin antibody (MAB2105; R\&D Systems Inc.), goat anti-GnRH antibody (sc-21140; Santa Cruz) or goat anti-cytokerin (sc-17091; Santa Cruz). Then, the cells were incubated in corresponding FITC-conjugated secondary antibody (Zhongshan Biotechnology, Beijing, China) at a dilution of 1:100 in PBS for $1 \mathrm{~h}$ at $37^{\circ} \mathrm{C}$. Nuclei were stained with $10 \mu \mathrm{g} / \mathrm{ml}$ propidium iodide (PI) for $10 \mathrm{~min}$ and viewed under a laser scanning confocal microscope (Leica, Heidelberg, Germany). As a negative control, parallel experiments were performed with cells using pre-immune goat or rabbit serum.

Cell proliferation analysis. JAR cells were plated in 6-well plates $24 \mathrm{~h}$ before BrdU incorporation analysis. Recombinant mouse Wnt5a (mWnt5a; 645-WN; R\&D Systems Inc.) at concentrations of $0,100,200$ and $400 \mathrm{ng} / \mathrm{ml}$ were added to the medium. To label cells in the S-phase of the cell cycle, $40 \mu \mathrm{M}$ BrdU (10280879001; Roche, Indianapolis, IN, USA) was added to the medium for $4 \mathrm{~h}$ before analysis. The cells were subsequently harvested and fixed in $100 \%$ cold methanol for $10 \mathrm{~min}$, washed two times in PBS, incubated in $2 \mathrm{M} \mathrm{HCl}$ for 45 min to denature the DNA, washed in PBS again and finally neutralized with $0.1 \mathrm{M} \mathrm{Na}_{2} \mathrm{~B}_{4} \mathrm{O}_{7}$ for $30 \mathrm{~min}$. After several washes in PBS, the cells were incubated with antiBrdU antibody (ZM0013; Zhongshan Biotechnology), then the appropriate FITC-labelled secondary antibody (ZF-0312; Zhongshan Biotechnology) was added, followed by an additional incubation for $45 \mathrm{~min}$ at $37^{\circ} \mathrm{C}$. Staining to determine the number of cells was performed by the addition of $10 \mu \mathrm{g} /$ $\mathrm{ml}$ PI followed by incubation for $10 \mathrm{~min}$ at room temperature, and was visualized using a confocal microscope (Leica). Cells were quantified by counting the number of BrdU-positive cells as PI-positive cells in 5-8 alternative areas. Each experiment comprised at least three independent cultures.

Cell growth curve. For the analysis of cell growth, JAR cells were plated at $1 \times 10^{4}$ in each of the 24-well plates and cultured in medium containing $0.5 \%$ FBS, with or without mWnt5a treatment. Viable cells (JAR and JAR-mWnt5a) were counted from days 1-7 using a hemocytomer. The results were obtained from three independent cultures.

Apoptosis analysis. Twenty-four hours after mWnt5a treatment, cells were harvested by trypsin and stained using an Annexin V FITC Apoptosis Detection kit (Biosea Biotechnology Co. Ltd., Beijing, China) according to the manufacturer's protocol. Stained cells were immediately analyzed by flow cytomtery (FACSCalibur; BioRad, USA). Apoptotic cells with exposed phosphatidylserine bound to Annexin V-FITC. Each experiment was repeated at least three times.

Statistical analysis. Values were presented as the mean \pm SEM. The data were analyzed using one-way ANOVA as appropriate. P-values $<0.05$ were considered statistically significant.

\section{Results}

Enrichment of CTB cells in vitro. More than 30 human samples were acquired, and isolated CTB cells were assessed as cells positively stained for cytokeratin and $\mathrm{GnRH}$, and negative for vimentin (Fig. 1).

Abnormal expression of Wnt5a in human choriocarcinoma cell line JAR. JAR cells were selected as a model of human placental choriocarcinoma, and established from a trophoblastic tumor of the placenta of a 24-year-old Caucasian woman (16). The expression level of Wnt5a in both the CTB and JAR cells was analyzed by RT-PCR and immunofluorescence. Wnt5a was found to be expressed in CTB cells, but was not detected in JAR cells (Fig. 2). This indicates that Wnt5a had an unknown effect on placental choriocarcinoma.

Effects of Wnt5a on the proliferation and growth of JAR cells. The proliferation of the JAR cells was investigated through BrdU incorporation after treatment with various concentrations of mWnt5a. mWnt5a at a concentration of $100 \mathrm{ng} / \mathrm{ml}$ was found to decrease the proliferation of JAR significantly compared to control (Fig. 3), while $200 \mathrm{ng} / \mathrm{ml} \mathrm{mWnt5a} \mathrm{had} \mathrm{an}$ even greater inhibitory effect on JAR proliferation. However, 

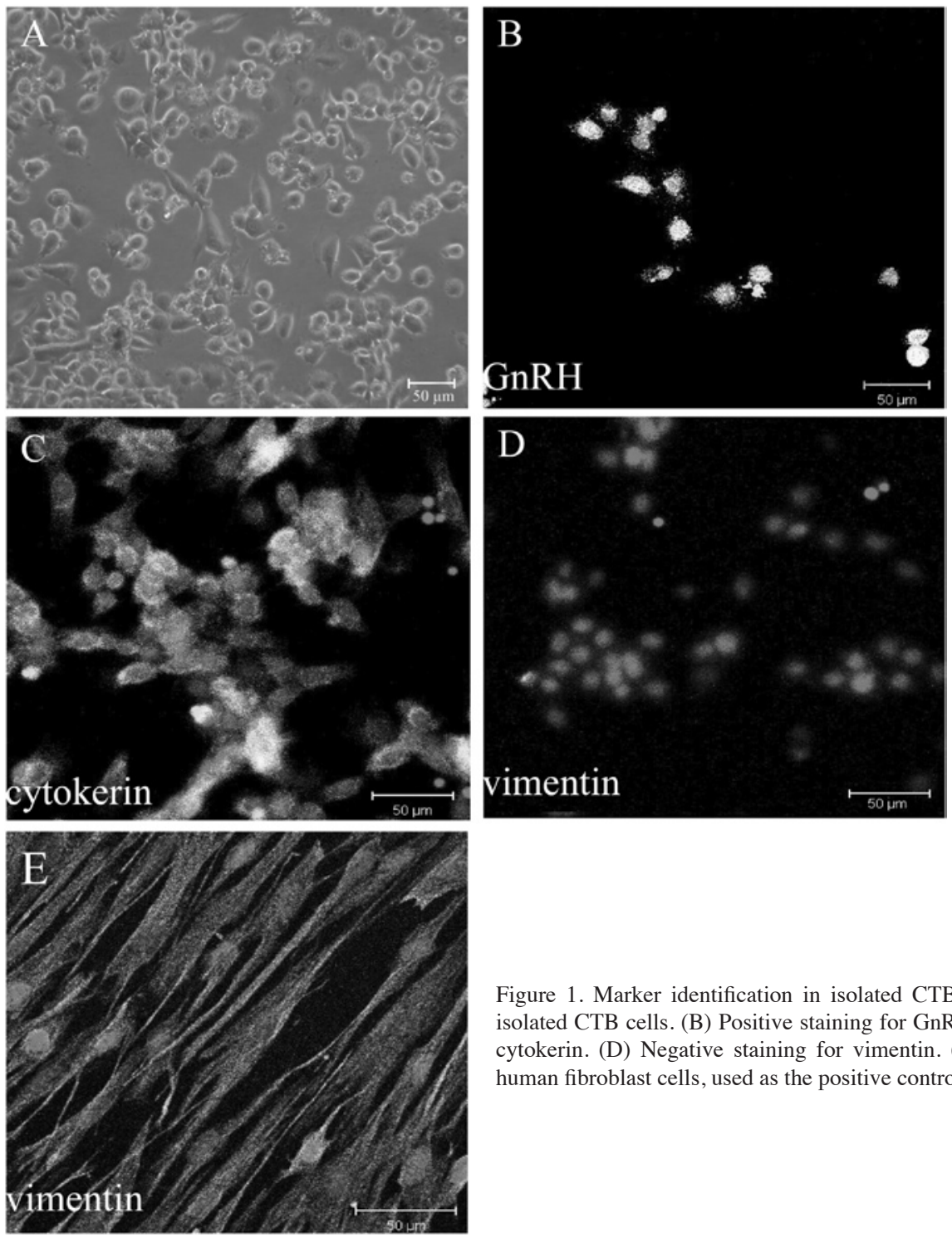

Figure 1. Marker identification in isolated CTB cells. (A) Morphology of isolated CTB cells. (B) Positive staining for GnRH. (C) Positive staining for cytokerin. (D) Negative staining for vimentin. (E) Vimentin expression in human fibroblast cells, used as the positive control. Bars, $50 \mu \mathrm{m}$.

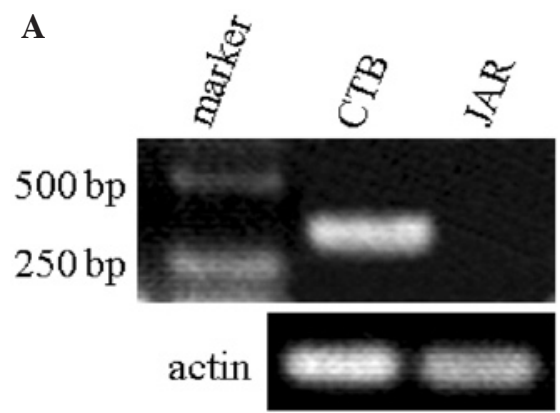

B

C
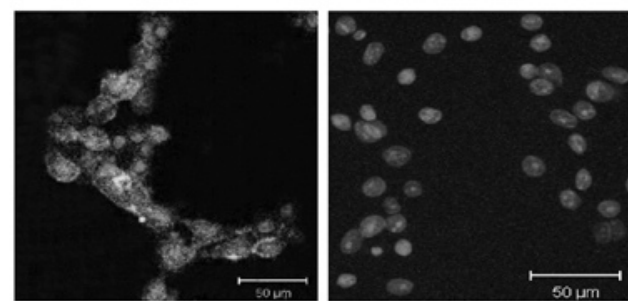

Figure 2. Wnt5a expression in JAR cells, but not in primary CTB cells. (A) Analysis of Wnt5a expression in CTB and JAR cells by PCR electrophoresis (B) Positive staining of Wnt5a in primary CTB cells. (C) Negative staining of Wnt5a in JAR cells. Bars, $50 \mu \mathrm{m}$.

the differences observed between the effects of 200 and $400 \mathrm{ng} / \mathrm{ml} \mathrm{mWnt5a}$ were not significant (Fig. 3).

To examine the effect of mWnt5a on cell growth, JAR cells were cultured in DMEM containing 0.5\% FBS and $100 \mathrm{ng} /$ $\mathrm{ml} \mathrm{mWnt5a}$ for 7 days. The result indicated that mWnt5a suppressed the cell growth of JAR (Fig. 4). These results taken together suggest a possible anti-tumor function of Wnt5a.
Effects of Wnt5a on the apoptosis of JAR cells and the localization of $\beta$-catenin. In order to study the role of Wnt5a in serum starvation-induced apoptosis, JAR cells were cultured in DMEM containing 0.5\% FBS and $100 \mathrm{ng} / \mathrm{ml} \mathrm{mWnt5a}$ for $24 \mathrm{~h}$. Wnt5a was found to markedly increase serum starvation-induced apoptosis in JAR cells compared to the control group without Wnt5a treatment (Fig. 5). This further supports 
A
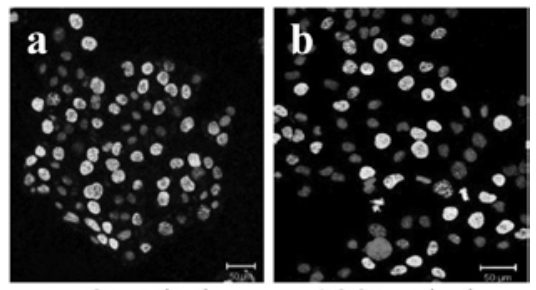

$0 \mathrm{ng} / \mathrm{ml}$

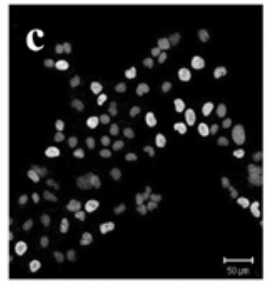

$200 \mathrm{ng} / \mathrm{ml}$

B

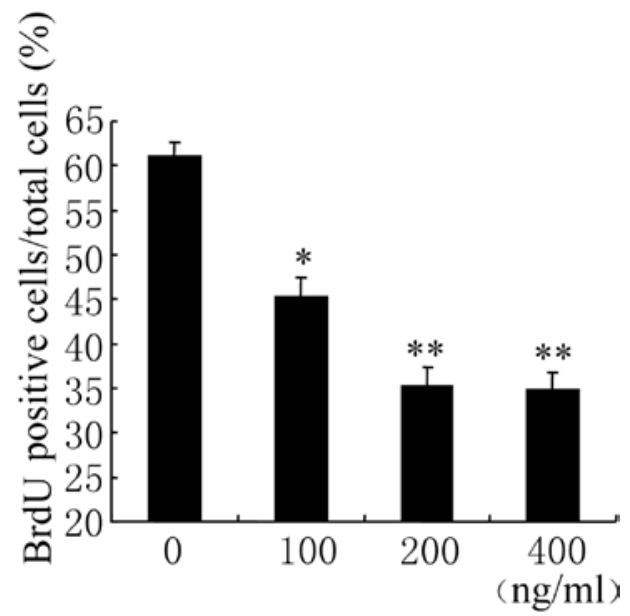

Figure 3. Effect of mWnt5a proteins on the proliferation of JAR cells. (A) Effect of recombinant mWnt5a at concentrations of (a) $0 \mathrm{ng} / \mathrm{ml}$, (b) $100 \mathrm{ng} / \mathrm{ml}$, (c) $200 \mathrm{ng} / \mathrm{ml}$ and (d) $400 \mathrm{ng} / \mathrm{ml}$ on the proliferation of JAR cells. (B) Quantitative measurement of the percentage of BrdU-positive cells Analyses were performed three times in independent experiments, and cells were counted in five fields per case. ${ }^{*} \mathrm{P}<0.05,{ }^{* *} \mathrm{P}<0.01$

our hypothesis that the carcinogenesis of placental choriocarcinoma may be correlated with the loss function of Wnt5a during pregnancy. Moreover, $\mathrm{LiCl}$, a well-known glycogen synthase kinase- 3 inhibitor, was found to promote the accumulation of $\beta$-catenin in the cytoplasm and nuclei of the JAR cells compared to the control cells (Fig. 6A and B). mWnt5a inhibited this $\mathrm{LiCl}$-induced $\beta$-catenin accumulation (Fig. 6C). This suggests that Wnt5a may antagonize the canonical Wnt signaling pathway in JAR cells.

\section{Discussion}

The results of the present study suggest that Wnt5a suppresses the carcinogenesis of placental choriocarcinoma by decreasing the proliferation and promoting the apoptosis of human choriocarcinoma cells, possibly through the inhibition of the canonical Wnt signaling pathway.

The effects of Wnt5a on the modulation of cellular activity during vertebrate development have been thoroughly demonstrated (17). Recent studies indicate that Wnt5a may play a critical role in tumorigenesis, though this finding is controver-

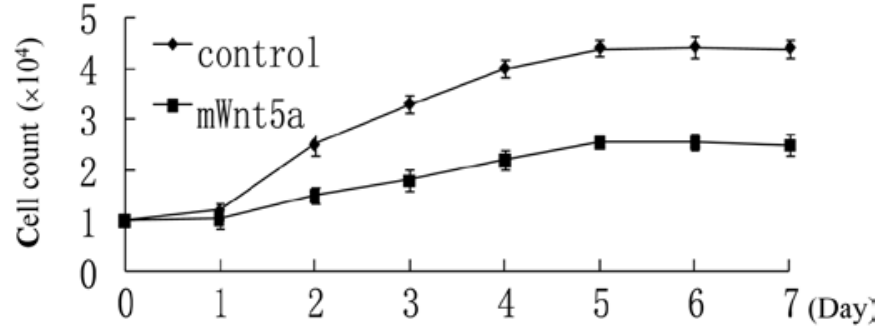

Figure 4. Effect of mWnt5a proteins on the growth of JAR cells. Viable cells were counted from days 1-7. JAR cells without Wnt5a treatment were used as a control. The number of viable cells was higher in JAR-mWnt5a than in JAR cells from days 2-6 $(\mathrm{P}<0.05)$.

sial $(13,18,19)$. In prostate and lung cancer, Wnt5a promoted tumor aggression $(13,18)$, while in thyroid carcinoma it suppressed tumor activity (19). The exact function of Wnt5a during the carcinogenesis of placental choriocarcinoma hasnot previously been elucidated.

In the present study, we first observed the lack of Wnt5a expression in JAR cells compared to CTB cells, and hypothesized that the abnormal expression of Wnt5a during pregnancy contributes to the carcinogenesis of placental choriocarcinoma. To support this hypothesis, we examined whether Wnt5a treatment affects apoptosis and proliferation in JAR cells.

The role of Wnt5a in proliferation is complex. Wnt5a has been found to promote the proliferation of human glioblastoma (20) and pancreatic cancer cells in vitro (21), but to suppress the proliferation of B cells (22) and colorectal cancer cells (23). Based on these studies, the effects of Wnt5a on cell proliferation are dependent on cell type. The results of the present study revealed that recombinant $\mathrm{mWnt} 5$ a protein inhibited the proliferation of JAR cells. This suggests that Wnt5a has tumor suppressor activity in human placental choriocarcinomas.

Although rapid progress has been made in elucidating the proliferative effects of Wnt5a, relatively little is known regarding its apoptotic or anti-apoptotic functions. Several recent studies have indicated that Wnt5a has anti-apoptotic action in specific cells, such as dermal fibroblasts and lung fibroblasts $(24,25)$. In this study, we investigated whether Wnt5a causes the apoptosis of JAR cells. Unexpectedly, mWnt5a was observed to significantly promote serum starvation-induced apoptosis in the JAR cells. Since the deregulation of apoptosis has been found to be involved in cancer initiation (26), we speculate that Wnt5a may act as a tumor suppressor in human placental choriocarcinomas by stimulating the apoptosis and inhibiting the proliferation of the choriocarcinoma cells.

It is generally believed that Wnt5a acts though the noncanonical $\mathrm{Wnt} / \mathrm{Ca}^{2+}$ signaling pathway $(10,11)$. However, a few investigations have demonstrated that non-canonical Wnt ligands inhibit canonical Wnt signaling in transformed cell lines, Xenopus embryos and mouse embryos (27,28). Wnt5a has been shown to induce Siah2, a member of an E3 ubiquitin ligase complex that targets $\beta$-catenin for degradation, and Wnt5a-deficient mice exhibited increased levels of $\beta$-catenin in the distal hind limb (28). Wnt5a also inhibited canonical Wnt signaling downstream of $\beta$-catenin stabilization through the calcium-dependent activation of Nemo-like kinase (29), as well as other calcium-independent mechanisms (30). Generally, the 
A

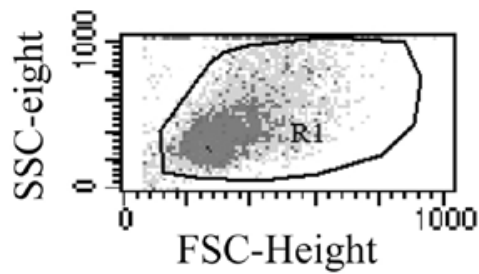

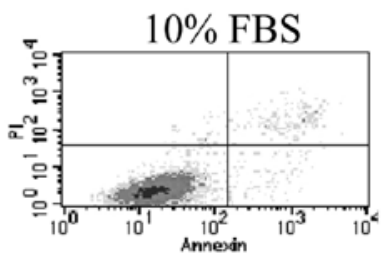

JAR

B

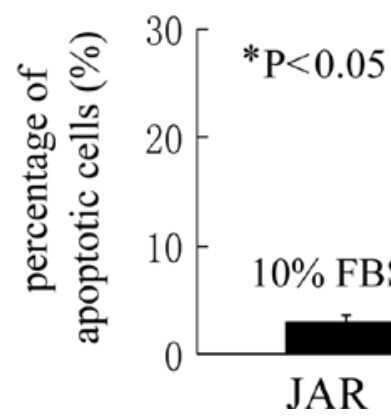

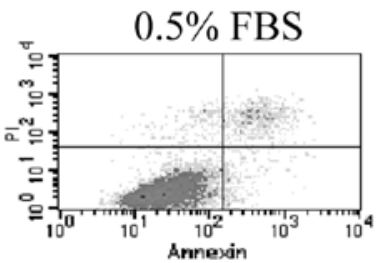

JAR

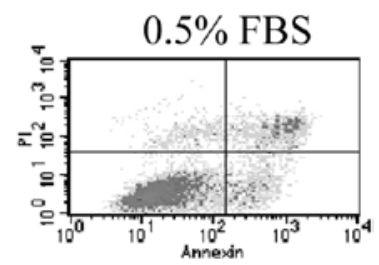

JAR-mWnt5a

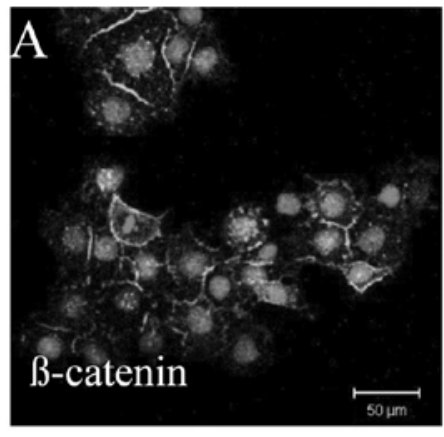

JAR

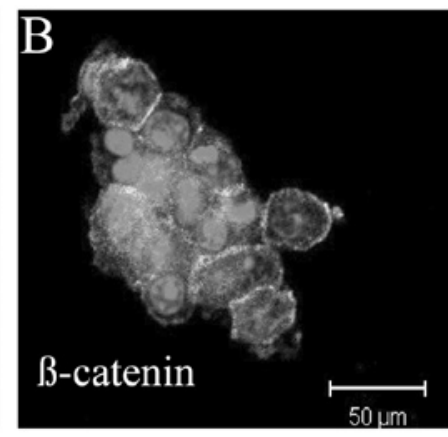

JAR-LiCl

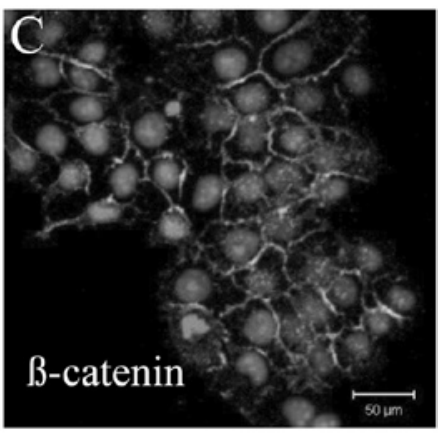

JAR-LiCl+mWnt5a

Figure 6. mWnt5a-induced inhibition of canonical Wnt/ $\beta$-catenin signaling activated by LiCl in JAR cells. (A) $\beta$-catenin located in the membrane of JAR cells. (B) $\beta$-catenin translocated to the cytoplasm and nucleus of JAR cells after stimulation with $25 \mathrm{mM} \mathrm{LiCl}$ for $24 \mathrm{~h}$. (C) $\beta$-catenin accumulation in the membrane of JAR cells after stimulation with $25 \mathrm{mM} \mathrm{LiCl}$ and $100 \mathrm{ng} / \mathrm{ml} \mathrm{mWnt5a}$ for $24 \mathrm{~h}$. Bars, $50 \mu \mathrm{m}$.

canonical Wnt pathway is considered activated when $\beta$-catenin is found expressed in the nuclei (31). Thus, although we did not examine changes in $\mathrm{Ca}^{2+}$ levels or the activation of PKC and CaMKII in JAR cells in our experiments, the absence of $\beta$-catenin in the cytoplasm and nucleus after Wnt5a treatment indicates that Wnt5a may suppress the activation of the canonical Wnt/ $\beta$-catenin pathway in JAR cells (32). Whether Wnt5a dependent non-canonical $\mathrm{Wnt} / \mathrm{Ca}^{2+}$ signaling is involved in Wnt5a regulation during the carcinogenesis of human placental choriocarcinoma requires further investigation.
In conclusion, in the present study, mWnt5a proteins not only inhibited cell growth, but also stimulated the apoptosis of human choriocarcinoma cells. This suggests that Wnt5a has a tumor suppressor effect on placental choriocarcinoma. The findings provide novel insight into the roles of Wnt signaling, and suggest the potential application of Wnt5a in the treatment of human placental choriocarcinomas. However, the exact molecular mechanisms of the effects of Wnt5a on the proliferation and apoptosis of JAR cells remain unclear, and require further investigation. 


\section{Acknowledgements}

This study was supported by a Northwest A\&F University start-up grant for post-graduate research 2008 (No. 01140406).

\section{References}

1. Janneau JL, Maldonado-Estrada J, Tachdjian G, Miran I, Motte N, Saulnier P, Sabourin JC, Cote JF, Simon B, Frydman R, Chaouat $\mathrm{G}$ and Bellet D: Transcriptional expression of genes involved in cell invasion and migration by normal and tumoral trophoblast cells. J Clin Endocrinol Metab 87: 5336-5339, 2002.

2. Karmakar S, Dhar R and Das C: Inhibition of cytotrophoblastic (JEG-3) cell invasion by interleukin 12 involves an interferon gamma-mediated pathway. J Biol Chem 279: 55297-55307, 2004.

3. Willert K, Brown JD, Danenberg E, Duncan AW, Weissman IL, Reya T, Yates JR III and Nusse R: Wnt proteins are lipidmodified and can act as stem cell growth factors. Nature 423 448-452, 2003

4. Miller JR, Hocking AM, Brown AM and Moon RT: Mechanism and function of signal transduction by the Wnt/beta-catenin and Wnt/Ca2+ pathways. Oncogene 18: 7860-7872, 1999.

5. Moon RT, Brown JD and Torres M: Wnts modulate cell fate and behaviour during vertebrate development. Trends Genet 13: $157-162,1997$.

6. Wodarz A and Nusse R: Mechanisms of Wnt signaling in development. Annu Rev Cell Dev Biol 14: 59-88, 1998.

7. Moon RT, Kohn AD, De Ferrari GV and Kaykas A: WNT and beta-catenin signalling: diseases and therapies. Nat Rev Genet 5: 691-701, 2004.

8. Clevers H: Wnt/beta-catenin signaling in development and disease. Cell 127: 469-480, 2006.

9. Oishi I, Suzuki H, Onishi N, Takada R, Kani S, Ohkawara B, Koshida I, Suzuki K, Yamada G, Schwabe GC, Mundlos S, Shibuya H, Takada S and Minami Y: The receptor tyrosine kinase Ror2 is involved in non-canonical Wnt5a/JNK signalling pathway. Genes Cells 8: 645-654, 2003.

10. Slusarski DC, Yang-Snyder J, Busa WB and Moon RT: Modulation of embryonic intracellular $\mathrm{Ca} 2+$ signaling by Wnt-5A. Dev Biol 182: 114-120, 1997.

11. Kuhl M, Sheldahl LC, Malbon CC and Moon RT: $\mathrm{Ca}(2+) / \mathrm{calm}-$ odulin-dependent protein kinase II is stimulated by Wnt and Frizzled homologs and promotes ventral cell fates in Xenopus. J Biol Chem 275: 12701-12711, 2000 .

12. Sidhu SS, Nawroth R, Retz M, Lemjabbar-Alaoui H, Dasari V and Basbaum C: EMMPRIN regulates the canonical Wnt/betacatenin signaling pathway, a potential role in accelerating lung tumorigenesis. Oncogene 29: 4145-4156, 2010

13. Yamamoto $H$, Oue N, Sato A, Hasegawa $Y$, Yamamoto $H$, Matsubara A, Yasui W and Kikuchi A: Wnt5a signaling is involved in the aggressiveness of prostate cancer and expression of metalloproteinase. Oncogene 29: 2036-2046, 2010.

14. Hibi K, Mizukami H, Goto T, Kitamura Y, Sakata M, Saito M, Ishibashi K, Kigawa G, Nemoto H and Sanada Y: WNT5A gene is aberrantly methylated from the early stages of colorectal cancers. Hepatogastroenterology 56: 1007-1009, 2009.

15. Xu P, Wang Y, Piao Y, Bai S, Xiao Z, Jia Y, Luo S and Zhuang L: Effects of matrix proteins on the expression of matrix metalloproteinase-2, -9, and -14 and tissue inhibitors of metalloproteinases in human cytotrophoblast cells during the first trimester. Biol Reprod 65: 240-246, 2001
16. Pattillo RA, Gey GO, Delfs E, Huang WY, Hause L, Garancis DJ, Knoth M, Amatruda J, Bertino J, Friesen HG and Mattingly RF: The hormone-synthesizing trophoblastic cell in vitro: a model for cancer research and placental hormone synthesis. Ann NY Acad Sci 172: 288-298, 1971.

17. Cadigan KM and Nusse R: Wnt signaling: a common theme in animal development. Genes Dev 11: 3286-3305, 1997.

18. Huang Y, Liu G, Zhang B, Xu G, Xiong W and Yang H: Wnt-5a regulates proliferation in lung cancer cells. Oncol Rep 23: 177-181, 2010.

19. Kremenevskaja N, von Wasielewski R, Rao AS, Schöfl C, Andersson T and Brabant G: Wnt-5a has tumor suppressor activity in thyroid carcinoma. Oncogene 24: 2144-2154, 2005.

20. Yu JM, Jun ES, Jung JS, Suh SY, Han JY, Kim JY and Jung JS: Role of Wnt5a in the proliferation of human glioblastoma cells. Cancer Lett 257: 172-181, 2007.

21. Ripka S, König A, Buchholz M, Wagner M, Sipos B, Klöppel G, Downward J, Gress T and Michl P: WNT5A-target of CUTL1 and potent modulator of tumor cell migration and invasion in pancreatic cancer. Carcinogenesis 28: 1178-1187, 2007.

22. Liang H, Chen Q, Coles AH, Anderson SJ, Pihan G, Bradley A, Gerstein R, Jurecic R and Jones SN: Wnt5a inhibits B cell proliferation and functions as a tumor suppressor in hematopoietic tissue. Cancer Cell 4: 4349-4360, 2003.

23. Ying J, Li H, Yu J, Ng KM, Poon FF, Wong SC, Chan AT, Sung JJ and Tao Q: WNT5A exhibits tumor-suppressive activity through antagonizing the Wnt/beta-catenin signaling, and is frequently methylated in colorectal cancer. Clin Cancer Res 14: 55-61, 2008.

24. Torii K, Nishizawa K, Kawasaki A, Yamashita Y, Katada M, Ito M, Nishimoto I, Terashita K, Aiso S and Matsuoka M: Antiapoptotic action of Wnt5a in dermal fibroblasts is mediated by the PKA signaling pathways. Cell Signal 20: 1256-1266, 2008.

25. Vuga LJ, Ben-Yehudah A, Kovkarova-Naumovski E, Oriss T, Gibson KF, Feghali-Bostwick C and Kaminski N: WNT5A is a regulator of fibroblast proliferation and resistance to apoptosis. Am J Respir Cell Mol Biol 41: 583-589, 2009.

26. Brown JM and Attardi LD: The role of apoptosis in cancer development and treatment response. Nat Rev Cancer 5: 231-237, 2005.

27. Torres MA, Yang-Snyder JA, Purcell SM, DeMarais AA, McGrew LL and Moon RT: Activities of the Wnt-1 class of secreted signaling factors are antagonized by the Wnt-5A class and by a dominant negative cadherin in early Xenopus development. J Cell Biol 133: 1123-1137, 1996.

28. Topol L, Jiang X, Choi H, Garrett-Beal L, Carolan PJ and Yang Y: Wnt-5a inhibits the canonical Wnt pathway by promoting GSK-3independent beta-catenin degradation. J Cell Biol 162: 899-908, 2003.

29. Ishitani T, Kishida S, Hyodo-Miura J, Ueno N, Yasuda J, Waterman M, Shibuya H, Moon RT, Ninomiya-Tsuji J and Matsumoto K: The TAK1-NLK mitogen-activated protein kinase cascade functions in the Wnt-5a/Ca(2+) pathway to antagonize Wnt/beta-catenin signaling. Mol Cell Biol 23: 131-139, 2003.

30. Mikels AJ and Nusse R: Purified Wnt5a protein activates or inhibits beta-catenin-TCF signaling depending on receptor context. PLoS Biol 4: 570-582, 2006.

31. Van de Wetering M, Sancho E, Verweij C, et al: The betacatenin/TCF-4 complex imposes a crypt progenitor phenotype on colorectal cancer cells. Cell 111: 241-250, 2002.

32. Wallingford JB, Vogeli KM and Harland RM: Regulation of convergent extension in Xenopus by Wnt5a and Frizzled-8 is independent of the canonical Wnt pathway. Int J Dev Biol 45: 225-227, 2001. 